\title{
Sodium chloride composition of commercial white bread in Morocco
}

Ali Jafri ${ }^{1}$, Younes El-Kardi ${ }^{7}$ and Abdelfettah Derouiche ${ }^{1}$

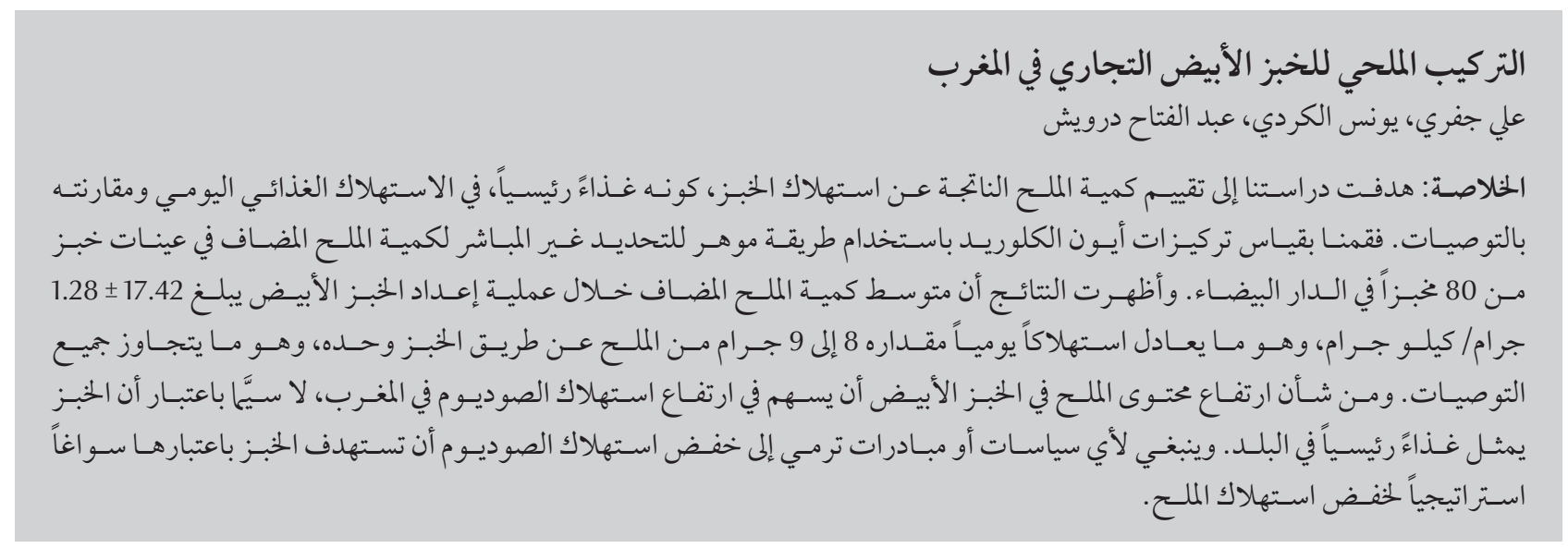

ABSTRACT This study aimed to evaluate the amount of salt provided by the consumption of bread in daily food intake and compare it to recommended salt intake. Chloride ion concentrations were measured using Mohr's Method to indirectly quantify added salt in bread samples from 80 professional bakeries in Casablanca, Morocco. Results showed that the average amount of added salt during the preparation of white bread is 17.42 $\pm 1.28 \mathrm{~g} / \mathrm{kg}$, which is the equivalent of a daily intake of 8 to $9 \mathrm{~g}$ of salt through bread alone, and exceeds all recommendations. The high salt content of white bread might be a contributing factor to the high sodium intake in Morocco, especially considering that bread is a staple food in the country. Any policies or initiatives to reduce sodium consumption should target bread as a strategic vehicle to reduce salt intake.

\section{Teneur en chlorure de sodium du pain blanc commercial au Maroc}

RÉSUMÉ La présente étude visait à évaluer la quantité de sel qu'apporte la consommation de pain dans I'alimentation quotidienne et à la comparer aux doses recommandées. La concentration d'ions chlorure a été mesurée à l'aide de la méthode de Mohr pour quantifier de façon indirecte le sel ajouté dans les échantillons de pain provenant de 80 boulangeries professionnelles à Casablanca (Maroc). Les résultats ont montré que la quantité moyenne de sel ajouté dans la confection du pain blanc est de 17,42 $\pm 1,28 \mathrm{~g} / \mathrm{kg}$. Ceci représente un apport journalier de 8 à 9 grammes de sel provenant uniquement de la consommation du pain et dépasse toutes les recommandations. La haute teneur en sel du pain blanc pourrait être un facteur qui contribue à la forte consommation de sodium au Maroc, surtout quand nous savons que le pain est un aliment de base dans le pays. Toutes les politiques et initiatives visant à réduire la consommation de sodium devraient cibler le pain comme outil stratégique pour réduire l'apport en sel. 


\section{Introduction}

High blood pressure is a serious public health problem in Morocco; in 2000, the national survey of cardiovascular risk factors in Morocco found 33.6\% of adults aged over 20 years had high blood pressure (1). In 2008, the World Health Organization (WHO) estimated the prevalence of raised blood pressure in Moroccan adults to be $32.4 \%$ (2). Evidence shows that high intake of sodium leads to hypertension, heart attacks and strokes, and several population-based studies around the world have reported that high salt intake is associated with elevated blood pressure (3).

In Morocco, bread is a staple food; its daily consumption can reach $500 \mathrm{~g}$ per person per day (4), which makes it a potentially important source of sodium.

This study aimed to measure the amount of added salt in commercial white bread, which would provide an estimate of salt intake in Morocco, and compare it with recommended levels of salt intake.

\section{Methods}

We used convenience sampling to collect bread samples from 80 of 320 bakeries in 3 regions of Casablanca. These regions had different water sources at the time of the study (February-April 2011). Two kinds of samples were collected from each outlet, samples from regular bread (prepared with salt) and samples from diet bread (prepared without adding salt). The samples of diet bread were used as the reference to control for the added salt and the quality of water (its chloride composition).

Added salt was estimated by measuring chloride ion concentration using Mohr's method (5).

1. Bread samples were diluted by adding $5 \mathrm{~g}$ of bread to $40 \mathrm{~mL}$ of water.

2. The solution was filtered and a $10 \mathrm{~mL}$ aliquot was collected in a conical flask.

3. Ten drops of potassium chromate $(0.05 \mathrm{~mol} / \mathrm{L})$ were added to the aliquot.

4. Titration was done using a solution of silver nitrate $(0.05 \mathrm{~mol} / \mathrm{L})$. The endpoint was identified as the first appearance of a red-brown colour of silver chromate.

Given that sodium chloride is not the only source of chloride ions, we used diet bread as the control since it is supposed to have the same ingredients as regular bread except for the added salt. Thus, the extra amount of chloride found in regular bread should be the equivalent of the chloride from the added salt. A calibration range was prepared using known concentrations of sodium chloride.

Statistical analysis was done using SPSS, version 23. We used the ShapiroWilk test to verify normality of the data and one-way analysis of variance to compare the 3 surveyed regions.

\section{Results}

The salt content of commercial white bread was not normally distributed in our sample according to the ShapiroWilk test $(W=0.984, P=0.4)$.

The diet bread had a mean of 0.032 (SD 0.012) mol of chloride per $\mathrm{kg}$ of bread, whereas regular bread had mean of 0.329 (SD 0.072) mol of chloride per $\mathrm{kg}$ (Table 1). Therefore, the mean amount of salt added during the preparation of regular white bread was 17.37 $(\mathrm{SD} 4.23) \mathrm{g} / \mathrm{kg}$ (Table 1). The salt content was not significantly different between the 3 surveyed regions ( $P>$ $0.05)$, although it varied between 8.4 and $30.0 \mathrm{~g}$ per $\mathrm{kg}$ of bread.

Only $1.3 \%$ of the regular bread samples had a salt content lower than $10 \mathrm{~g}$ per $\mathrm{kg}$, which would meet the WHO recommendations, based on a $500 \mathrm{~g}$ daily intake (Table 2). The Moroccan Federation of Bakeries recommends adding the equivalent of $18 \mathrm{~g}$ of sodium chloride per kg of bread during the preparation of white bread (6). Results show that $38.8 \%$ of the samples exceeded both recommendations (Table 2).

Assuming individual bread consumption was $500 \mathrm{~g}$ a day (4), the consumption of regular white bread would result in the intake of $8.69 \mathrm{~g}$ of salt daily.

\begin{tabular}{|c|c|c|c|c|c|c|}
\hline \multirow[t]{2}{*}{ Region } & \multirow[t]{2}{*}{$\begin{array}{c}\text { No. of } \\
\text { samples }\end{array}$} & \multicolumn{2}{|c|}{$\begin{array}{c}\text { Mean (SD) chloride content in } 1 \mathrm{~kg} \text { of } \\
\text { bread (mol) }\end{array}$} & \multicolumn{3}{|c|}{ Added salt in regular bread $(\mathrm{g} / \mathrm{kg})$} \\
\hline & & Diet bread & Regular bread & Minimum & Maximum & Mean (SD) \\
\hline 1 & 88 & $0.032(0.012)$ & $0.329(0.073)$ & 10.8 & 30.0 & $17.39(4.33)$ \\
\hline 2 & 46 & $0.033(0.013)$ & $0.326(0.074)$ & 8.4 & 26.8 & $17.16(4.51)$ \\
\hline 3 & 26 & $0.031(0.011)$ & $0.334(0.067)$ & 12.0 & 23.2 & $17.70(4.65)$ \\
\hline Overall & 160 & $0.032(0.012)$ & $0.329(0.072)$ & 8.4 & 30.0 & $17.37(4.23)$ \\
\hline $\mathrm{F}$ & - & 0.114 & 0.042 & 0.067 & - & - \\
\hline$P$-value & - & 0.893 & 0.959 & 0.936 & - & - \\
\hline
\end{tabular}

$S D=$ standard deviation. 


\begin{tabular}{|c|c|c|}
\hline \multicolumn{3}{|c|}{$\begin{array}{l}\text { Table } 2 \text { Percentage of samples according to salt content cut-offs of World Health } \\
\text { Organization recommendations and the guidelines of the Moroccan Federation } \\
\text { of Bakeries }\end{array}$} \\
\hline \multicolumn{3}{|c|}{$\%$ of bread samples with salt content: } \\
\hline$\leq 10 \mathrm{~g} / \mathrm{kg}^{\mathrm{a}}$ & $>10 \mathrm{~g} / \mathrm{kg}$ to $\leq 18 \mathrm{~g} / \mathrm{kg}^{\mathrm{b}}$ & $>18 \mathrm{~g} / \mathrm{kg}$ \\
\hline 1.3 & 60.0 & 38.7 \\
\hline
\end{tabular}

${ }^{a}$ WHO cut-off; ${ }^{b}$ Moroccan Federation of Bakeries cut-off.

\section{Discussion}

The amount of added salt in commercial white bread available for consumption in Casablanca exceeds the recommendations set by the Institute of Medicine in the United States of America (7) and by WHO. The Institute of Medicine established the sufficient daily intake at $1500 \mathrm{mg}$ of sodium ( $3.75 \mathrm{~g}$ of salt) for people between 9 and 50 years of age, with lower levels for other ages. In addition, the Institute of Medicine established the maximum tolerated value of sodium at $2300 \mathrm{mg}$ (7.75 g of salt) for individuals of over 14 years old, and lower amounts for younger people. In 2003, WHO set the therapeutic target of daily sodium consumption at 2000 mg (5 g of salt) $(8,9)$.
Our results show that, through eating bread alone, the average sodium intake exceeds all these recommendations by at least $50 \%$. Several countries have implemented strategies to reduce sodium intake (3), either by encouraging manufacturers to reduce added sodium or by implementing a labelling system. A study about the acceptance of sodium reduction in white bread showed that a reduction by one quarter can be done in a short time without affecting consumer acceptance (10). These measures and policies contributed to a decrease in overall blood pressure and reduction in heart attacks and strokes in the targeted populations (3). Indeed, lowering blood pressure in the population, even by small amounts, is likely to have a large benefit in preventing heart attacks and strokes (3).

\section{Conclusion}

Our study highlights the high salt content in commercial white bread in Morocco. Given that bread is a staple food in the country, its consumption alone provides a daily intake of sodium chloride exceeding all recommendations and could be responsible for a high sodium intake in Morocco, which could lead to increased cardiovascular risk. In the absence of data about the exact salt intake in Morocco, we can only recommend using these data to raise awareness about salt over-consumption which may increase the prevalence of hypertension.

\section{Acknowledgements}

The authors acknowledgethe efforts and input of the late MrAbdellatifBoulgana, MSc, and the assistance of MrLahoussineAzaz, President of the FédérationNationale de la BoulangerieetPâtisserie du Maroc.

\section{Funding: None.}

Competing interests: None declared.

\section{References}

1. TaziMA, Abir-KhalilS, ChaoukiN, CherqaouiS, LahmouzF, SraïriJE, et al.Prevalence of the main cardiovascular risk factors in Morocco: results of a National Survey, 2000. J Hypertens. 2001;21(5):897-903.

2. Noncommunicable diseases country profiles 2011. Geneva:World Health Organization; 2011.

3. NessRB. Controversies in epidemiology and policy: salt reduction and prevention of heart disease. Ann Epidemiol. 2009;19(2):118-20.

4. Mokhtar N, Belhadj H, Kress D, Zerrari A, Chaouki N. Food-fortification program in Morocco. Food Nutr Bull. 2001;22(4):42730 .

5. YoderL. Adaptation of the Mohr volumetric method to general determinations of chlorine. J Ind Eng Chem. 1919;11(8):755.

6. BoulganaA. Teneur du seldans le pain des Boulangerscasablancaiscas de 80 boulangers-et prévention de I'hypertensionartérielle [Salt content in bakers' bread in Casa- blanca -case of 80 bakers -and prevention of high blood pressure]. Casablanca: Université Hassan II Mohammedia; 2011.

7. Panel on Dietary Reference Intakes for Electrolytes and Water -Standing Committee on the Scientific Evaluation of Dietary Reference Intakes. Dietary reference intakes for water, potassium, sodium, chloride, and sulfate. Washington, DC: Institute of Medicine; 2005.

8. Diet, nutrition and the prevention of chronic diseases: report of a joint WHO/FAO expert consultation. Geneva: World Health Organization; 2003.

9. Guideline: sodium intake for adults and children. Geneva: World Health Organization;2012.

10. Girgis S, Neal B, Prescott J, Prendergast J, Dumbrell S, Turner C, et al. A one-quarter reduction in the salt content of bread can be made without detection. EurJ ClinNutr. 2003;57(4):616-20. 